\title{
PENGARUH METODE PENGERINGAN SIMPLISIA TERHADAP KAPASITAS ANTIOKSIDAN WEDANG $\boldsymbol{U} W \boldsymbol{U}$
}

\section{EFFECT OF SIMPLISIA DRYING METHOD TO THE ANTIOXIDANT CAPACITY OF WEDANG UWUH}

\author{
Made Aditya Dharma ${ }^{1}$, K. A Nocianitri ${ }^{2}$, Ni Luh Ari Yusasrini ${ }^{3}$ \\ ${ }^{1}$ Mahasiswa Program Studi Ilmu dan Teknologi Pangan, Fakultas Teknologi Pertanian, Unud \\ ${ }^{2}$ Dosen Program Studi Ilmu dan Teknologi Pangan, Fakultas Teknologi Pertanian, Unud \\ Kampus Bukit Jimbaran, Badung-Bali
}

\begin{abstract}
This research aims to determine the effect of drying method the antioxidant capacity of wedang uwuh and to obtain the highest antioxidant capacity of wedang uwuh. This study was designed using a completely randomized design (CRD) with four parameters of drying methods there are sun-drying, air-drying, greenhouse and oven, which were repeated four times. Therewere many parameters analyzed in this research such as water content, antioxidant capacity, total phenol and sensoryincluding color, aroma, taste and overall acceptance. All data were statistically analyzed using ANOVA and continued with Duncan's (DMRT) $(\alpha=5 \%)$. The results showed that the drying method had a significant effect on the water content, antioxidant capacity and total phenol of wedang uwuh, but did not significantly affect to the sensory results. Airdrying method produced wedang uwuh with the highest antioxidant capacity of 63,63 mgGAEAC/L, with a moisture content of $8,05 \%$, and total phenol of $23,70 \mathrm{mg} / \mathrm{L}$ where, based on color, taste, flavor and general acceptance the panelists rather like the wedang uwuh produced.
\end{abstract}

Keywords: simplisia, wedang uwuh, drying, antioxidant

\section{PENDAHULUAN}

Wedang uwuh adalah minuman tradisional dari daerah Imogiri, Bantul, Yogyakarta. Wedang uwuh dipercaya memiliki khasiat sebagai penghangat tubuh, menyembuhkan batuk ringan, loyo, pegal-pegal, nyeri, perut kembung dan masuk angin. Wedang uwuh terbuat dari jahe, daun kayu manis, daun cengkeh dan daun pala, sebagian komposisi penyusunnya mengandung senyawa fenolat yang sangat aktif sebagai antioksidan. Antioksidan adalah senyawa yang dapat melindungi tubuh dari radikal bebas, yaitu reaksi berantai yang dapat menyebabkan penyakit degenerative (Kristianingrum, 2009).

Korespondensi Penulis : E-mail: Aditya.dharma10@gmail.com ${ }^{1)}$
Salah satu proses pasca panen yang berperan penting terhadap mutu simplisia adalah proses pengeringan (Departemen Kesehatan Republik Indonesia, 2000). Proses pengeringan berpengaruh terhadap kandungan senyawa kimia yang terkandung dalam suatu tanaman herbal terutama senyawa yang berkhasiat sebagai antioksidan. Kandungan fenolik dan flavonoid total dalam suatu simplisia yang mempunyai aktivitas antioksidan kestabilannya dapat dipengaruhi oleh proses pengeringan (Hernani, 2009).

Terdapat beberapa metode dalam pengeringan antara lain pengeringan dengan sinar matahari 
langsung, pengeringan dengan oven, kering angin dan pengeringan dengan rumah kaca. Pengeringan dengan sinar matahari, kering angin dan rumah kaca merupakan proses pengeringan yang paling mudah dilakukan namun memerlukan waktu yang lebih lama jika dibandingkan dengan pengeringan oven. Pengeringan oven dapat mengurangi kadar air dalam jumlah besar dalam waktu yang singkat (Muller et al, 2006). Sinar ultra violet dari matahari juga menimbulkan kerusakan pada kandungan kimia bahan yang dikeringkan. Pengeringan dilakukan untuk mendapatkan kadar air dibawah $10 \%$ bertujuan untuk mencegah tumbuhnya bakteri dan jamur pada tahap penyimpanan (Katno, 2008).

Penelitian sebelumnya yang dilakukan oleh Danthiswari dkk (2016) yang menggunakan perlakuan jahe merah dan dengan pengeringan buatan (oven) selama 2 jam didapatkan kandungan antioksidan wedang uwuh sebesar 112,22 mgGAEAC/L dan total fenol yaitu $88,36 \mathrm{mg} / \mathrm{L}$, Winarno (2002) menyatakan bahwa suhu dan lama pengeringan berpengaruh nyata terhadap aktivitas antioksidan karena dapat mengakibatkan rusaknya zat aktif yang terkandung dalam suatu bahan, maka dari itu perlu dilakukan penelitian untuk membandingkan empat metode pengeringan yaitu pengeringan sinar matahari langsung, kering angin, rumah kaca dan buatan (oven) pada pembuatan wedang uwuh.

\section{METODE PENELITIAN}

\section{Tempat dan Waktu Penelitian}

Penelitian ini dilaksanakan di Laboratorium Pengolahan Pangan, Laboratorium Analisis Pangan,
Laboratorium Rekayasa Proses dan Pengendalian Mutu, Fakultas Teknologi Pertanian, Universitas Udayana, kampus Sudirman, Denpasar dan Kampus Bukit Jimbaran, Penelitian ini dilaksanakan dari bulan Juli - Agustus 2018.

\section{Bahan dan Alat}

Bahan yang digunakan dalam penelitian ini meliputi bahan pembuatan wedang uwuh, seperti jahe merah yang diperoleh dari Pasar Kumba Sari, daun cengkeh yang diperoleh dari perkebunan di desa Munduk, Buleleng, daun pala dan daun kayu manis yang diperoleh dari Tabanan, Bali, gula merah, bahan untuk analisis seperti, methanol PA (Merck), 2,2-diphenyl-1-pircylhydrazyl (DPPH), asam galat, aquades, follin ciocalteu $50 \%, \mathrm{Na}_{2} \mathrm{CO}_{3}$, kertas saring, alumunium foil.

Alat yang digunakan dalam penelitian ini yaitu pisau, blender, talenan, panci stainless steel, kompor, gelas beker ukuran $500 \mathrm{ml}$, sendok, saringan, oven, spectrometer uv-vis 1240, tabung reaksi, vortex, gelas beker, erlenmeyer, labu takar, pipet mikro, pipet tetes, timbangan analitik, desikator dan alat uji organoleptik.

\section{Pelaksanaan Penelitian}

Penelitian ini dilaksanakan dengan menggunakan Rancangan Acak Lengkap (RAL), dengan perlakuan 4 metode pengeringan, yaitu: Pengeringan sinar matahari, Pengeringan kering angin, Pengeringan rumah kaca dan Pengeringan oven, masing-masing perlakuan diulang sebanyak 4 kali sehingga diperoleh 16 unit percobaan. Data yang diperoleh dari hasil penelitian dianalisis 
dengan sidik ragam (ANOVA) dan apabila terdapat pengaruh antar perlakuan maka dilanjutkan dengan uji Duncan's Multiple Range Test (DMRT) (Gomez dan Gomez, 1995).

\section{Pelaksanaan Penelitian}

Pelaksanaan penelitian ini dibagi menjadi 2 tahapan yaitu :

\section{Pengeringan simplisia}

Pengeringan simplisia dilakukan dengan 4 metode pengeringan diantaranya pengeringan sinar matahari, kering angin, rumah kaca dan oven. Proses pengeringan diawali dengan proses sortasi, kemudian dicuci dan dikeringkan sesuai dengan metode pengeringan hingga kadar air mencapai $\leq 10 \%$. Daun yang kering memiliki karakteristik yang mudah hancur jika diremas dan terjadi perubahan warna yang signifikan.

Pengeringan matahari dilakukan dengan menjemur daun dibawah sinar matahari. Pengeringan angin dilakukan ditempat yang tidak terkena matahari secara langsung. Pengeringan rumah kaca menggunakan alat yang menyerupai ruangan yang dapat menyimpan panas matahari. Pengeringan oven dilakukan pada suhu $50^{\circ} \mathrm{C}$ selama 150 menit.

\section{Pembuatan Wedang uwuh.}

Proses penyeduhan wedang uwuh diawali dengan menimbang daun pala 0,28 gram, daun cengkeh 1,68 gram, dan kayu manis 0,21 gram (total simplisia 2,17 gram) kemudian ditambahkan 26,45 gram jahe dan 22,13 gram gula merah dan diseduh dengan $300 \mathrm{ml}$ air mendidih (Danthiswari dkk, 2016).

\section{Parameter yang Diamati}

Variable yang diamati yaitu kadar air menggunakan metode oven (AOAC,1995) pada simplisia, kapasitas antioksidan menggunakan metode 2-diphenyl-1-picrylhydrazyl (DPPH) (Yun, 2001), total fenol menggunakan metode follinciocalteu (Andarwulan et al., 2011), dan evaluasi sensoris dengan menggunakkan metode uji hedonik dan uji skoring (Soekarto, 1985) pada seduhan wedang uwuh.

\section{HASIL DAN PEMBAHASAN}

Parameter yang diuji pada wedang uwuh adalah kadar air simplisia wedang uwuh, kapasitas, total fenol seduhan wedang uwuh, dengan empat perlakuan yaitu pengengeringan matahari, rumah kaca, kering angin dan oven.

\section{Kadar Air}

Berdasarkan hasil analisis ragam dapat disampaikan bahwa metode pengeringan berpengaruh nyata terhadap kadar air simplisia $(\mathrm{P}<0,05)$. Pengeringan sinar matahari dan pengeringan rumah kaca memiliki perbedaan yang nyata dengan pengeringan oven dan pengeringan kering angin. Pengeringan matahari dilakukan selama 5 hari, pengeringan rumah kaca dilakukan selama 10 hari, pengeringan kering angin dilakukan selama 12 hari dan pengeringan oven dilakukan selama 150 menit dengan suhu $50^{\circ} \mathrm{C}$. Metode 
Pengeringan berpengaruh nyata terhadap kadar air bahan, hal ini sejalan dengan penelitian yang dilakukan oleh Winangsih (2013) dimana metode pengeringan berpengaruh secara signifikan terhadap berat kering simplisia. Kadar air daun kering wedang uwuh dengan menggunakan berbagai metode pengeringan berkisar antara 7,88\% - 9,75\% . Pengeringan simplisia dengan kadar air tertinggi adalah pengeringan sinar matahari dengan kadar air 9,75\%. Pengeringan simplisia dengan kadar air terendah adalah pengeringan oven dengan kadar air

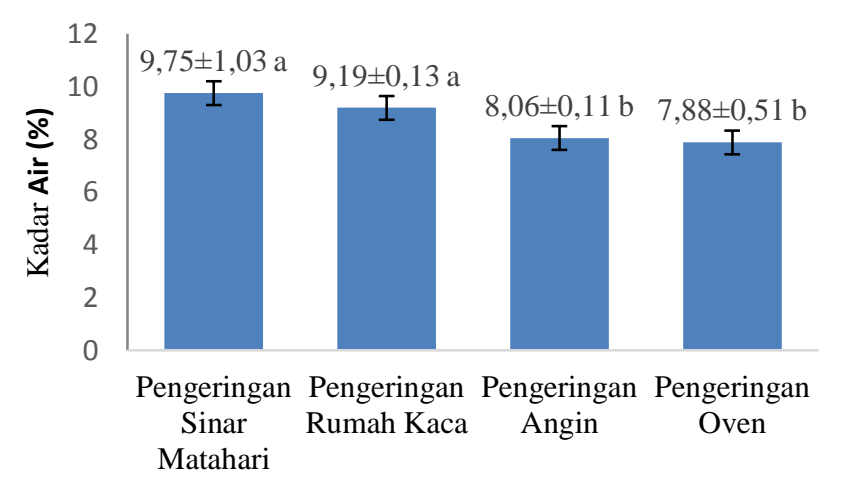

Gambar 1. Hubungan antara metode pengeringan dengan kadar air

Penelitian Rivai (2014) menunjukan bahwa hasil susut pengeringan juga tidak berbeda nyata antara simplisia yang dikeringkan dengan oven dan yang dikeringanginkan. Kadar air simplisia sebaiknya lebih kecil dari 10\%. Menurut Manoi (2006) apabila kadar air lebih besar dari 10\% akan menyebabkan terjadinya proses enzimatik dan kerusakan oleh mikroba. Penelitian Manoi (2006) menunjukan bahwa simplisia yang disimpan dalam waktu yang lama akan merubah kandungan kimia yang telah terbentuk menjadi produk lain oleh enzim, sehingga tidak lagi memiliki efek farmakologi seperti senyawa asalnya, hal ini tidak akan terjadi jika bahan yang telah dikeringkan mempunyai kadar air yang rendah. Beberapa enzim perusak kandungan kimia antara lain adalah hidrolase, oksidase dan polymerase. Susut pengeringan pada simplisia bahan wedang uwuh telah sesuai dengan standar Farmakope Herbal Indonesia Edisi I (2008) yaitu kurang dari $10 \%$.

\section{Total Fenol}

Berdasarkan hasil analisis sidik ragam dapat disampaikan bahwa metode pengeringan berpengaruh nyata terhadap total fenol air seduhan wedang uwuh $(\mathrm{P}<0,05)$. Total fenol seduhan wedang uwuh dengan metode pengeringan kering angin berbeda nyata dengan metode pengeringan yang lain, sedangkan metode pengeringan sinar matahari, rumah kaca, dan oven yang tidak memberikan perbedaan nyata terhadap total fenol seduhan wedang uwuh. Hubungan antara metode pengeringan dengan total fenol seduhan wedang uwuh dapat dilihat pada Gambar 2.

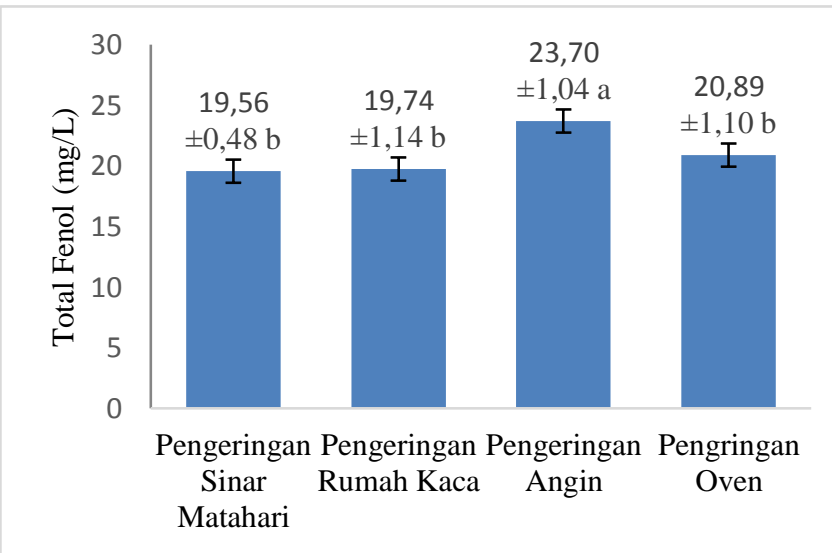

Gambar 2. Hubungan antara metode pengeringan dengan total fenol seduhan wedang uwuh 
Total fenol wedang uwuh dengan menggunakan berbagai metode pengeringan berkisar antara 19,74 mg/L - 23,70 mg/L. Total fenol tertinggi adalah air seduhan wedang uwuh yang dikeringkan dengan pengeringan kering angin dengan total fenol 23,70 $\mathrm{mg} / \mathrm{L}$. Pengeringan simplisia dengan total fenol terendah adalah pengeringan rumah kaca dengan total fenol 19,75 $\mathrm{mg} / \mathrm{L}$. Pengeringan kering angin merupakan pengeringan dengan paparan sinar matahari yang lebih sedikit jika dibandingkan dengan pengeringan langsung, sehingga memungkinkan suhu pengeringan kering angin merupakan suhu terendah jika dibandingkan dengan suhu metode pengeringan lainnya. Suhu pengeringan dengan sinar matahari berkisar antara $26-40^{\circ} \mathrm{C}$. Menurut Rivai et al., (2010) Suhu pengeringan berpengaruh terhadap perolehan kadar fenolat. Pengeringan daun dewa pada suhu $25^{\circ} \mathrm{C}$ memberikan kadar fenolat lebih besar daripada pengeringan dengan suhu $40^{\circ} \mathrm{C}$. Sedangkan pengeringan pada suhu $60^{\circ} \mathrm{C}$ menyebabkan penurunan kadar fenolat dengan hasil yang signifikan dibandingkan dengan pengeringan pada suhu $40^{\circ} \mathrm{C}$.

\section{Kapasitas Antioksidan}

Berdasarkan hasil uji analisis sidik ragam dapat disampaikan bahwa metode pengeringan berpengaruh nyata $(\mathrm{P}<0,05)$ terhadap kapasitas antioksidan air seduhan wedang uwuh. Hubungan antara metode pengeringan dengan kapasitas antioksidan seduhan wedang uwuh Gambar 3.

Pengeringan dengan sinar matahari memberikan pengaruh nyata terhadap kapasitas antioksidan, namun pangeringan rumah kaca dan pengeringan oven tidak memberikan pengaruh yang nyata terhadap kapasitas antioksidan air seduhan wedang uwuh. Kapasitas antioksidan wedang uwuh dengan menggunakan berbagai metode pengeringan berkisar antara 49,75 mgGAEAC/L - 63,63 mgGAEAC/L. Kapasitas antioksidan tertinggi adalah air seduhan wedang uwuh yang dikeringkan dengan metode pengeringan kering angin dengan kapasitas antioksidan 63,63 mgGAEAC/L. Kapasitas antioksidan terendah adalah pengeringan sinar matahari dengan kapasitas antioksidan 49,75 mgGAEAC/L, hal ini disebabkan karena simplisia terpapar sinar ultraviolet secara langsung. Menurut Winangsih (2013) sinar ultraviolet dari matahari menimbulkan kerusakan pada kandungan kimia bahan yang dikeringkan.

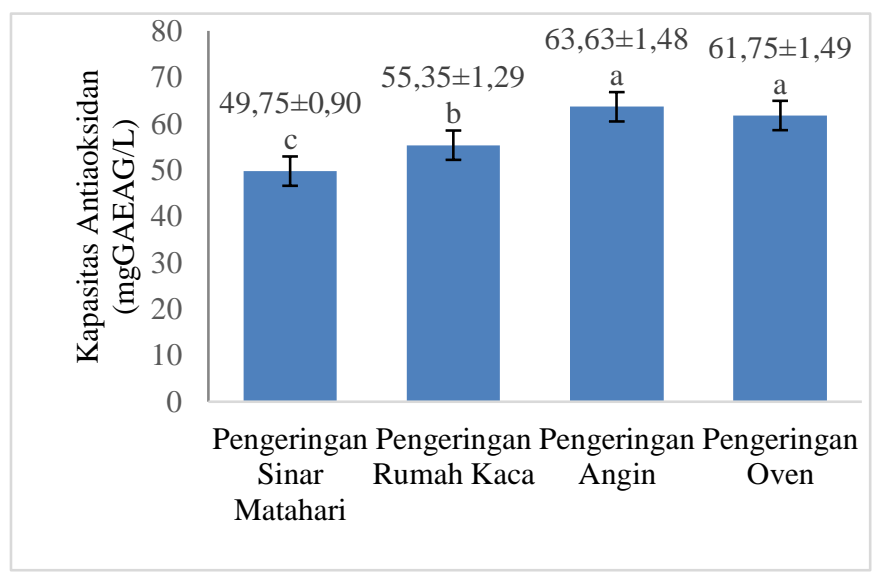

Gambar 3. Hubungan antara metode pengeringan dengan kapasitas antioksidan seduhan wedang uwuh

Keempat metode pengeringan tersebut mengalami penurunan aktivitas antioksidan seiring dengan suhu pengeringan yang semakin tinggi. Selain suhu, waktu pengeringan juga berpengaruh terhadap aktivitas antioksidan simplisia. Semakin 
tinggi suhu dan lama pengeringan yang digunakan menyebabkan aktivitas antioksidan juga semakin menurun. Dimana suhu dan lama pengeringan sinar matahari berkisar antara $28-33^{\circ} \mathrm{C}$ selama 5 hari, pengeringan kering angin berkisar $24-30^{\circ} \mathrm{C}$ selama 12 hari, pengeringan rumah kaca berkisar $26-36^{\circ} \mathrm{C}$ selama 10 hari dan pengeringan oven dengan suhu $50^{\circ} \mathrm{C}$ selama 150 menit. Hal ini sesuai dengan pernyataan Winarno (2002) bahwa suhu dan lama pengeringan berpengaruh nyata terhadap aktivitas antioksidan karena kondisi tersebut mengakibatkan rusaknya zat aktif yang terkandung dalam suatu bahan.

\section{Evaluasi Sensoris}

Penilaian evaluasi sensori dilakukan penerimaan keseluruhan panelis terhdap warna, rasa, aroma dan penerimaan keseluruhan.

Tabel 1. Hasil uji sensoris air seduhan wedang uwuh

\begin{tabular}{cccccc}
\hline & Skor & \multicolumn{4}{c}{ Hedonik } \\
\cline { 3 - 6 } Perlakuan & Warna & Rasa & Warna & Aroma & $\begin{array}{c}\text { Penerimaan } \\
\text { Keseluruhan }\end{array}$ \\
\cline { 3 - 6 } & & & & & \\
$\begin{array}{c}\text { Pengeringan } \\
\text { matahari }\end{array}$ & $4,46 \pm 0,66 a$ & $4,46 \pm 1,11 \mathrm{a}$ & $5,00 \pm 1,04 \mathrm{a}$ & $4,93 \pm 1,23 \mathrm{a}$ & $4,73 \pm 1,03 \mathrm{a}$ \\
$\begin{array}{c}\text { Pengeringan } \\
\text { keringangin }\end{array}$ & $4,66 \pm 0,48 \mathrm{a}$ & $4,26 \pm 1,16 \mathrm{a}$ & $5,06 \pm 0,81 \mathrm{a}$ & $5,00 \pm 0,64 \mathrm{a}$ & $4,80 \pm 0,72 \mathrm{a}$ \\
$\begin{array}{c}\text { Pengeringan } \\
\text { rumah kaca }\end{array}$ & $4,53 \pm 0,66 \mathrm{a}$ & $4,13 \pm 1,64 \mathrm{a}$ & $5,06 \pm 0,86 \mathrm{a}$ & $4,93 \pm 0,89 \mathrm{a}$ & $4,46 \pm 0,87 \mathrm{a}$ \\
$\begin{array}{c}\text { Pengeringan } \\
\text { oven }\end{array}$ & $4,66 \pm 0,63 \mathrm{a}$ & $4,26 \pm 0,88 \mathrm{a}$ & $5,13 \pm 1,07 \mathrm{a}$ & $4,73 \pm 1,19 \mathrm{a}$ & $4,53 \pm 0,77 \mathrm{a}$ \\
\hline
\end{tabular}

Keterangan : Nilai rata-rata yang diikuti oleh huruf yang sama pada kolom yang sama menunjukkan perbedaan yang tidak nyata $(\mathrm{P}>0,05)$.

\section{Warna}

Warna merupakan parameter yang berpengaruh terhadap penerimaan konsumen, dimana warna merupakan parameter pertama yang dilihat oleh konsumen. Analisis sidik ragam dapat disampaikan bahwa warna air seduhan wedang uwuh dengan berbagai metode berpengaruh tidak nyata $(\mathrm{P}>0,05)$. Hasil uji skoring terhadap warna seduhan wedang uwuh berkisar antara 4,46 - 4,66 (kuning kecokelatan). Nilai tertinggi yang diperoleh adalah air seduhan wedang $u$ wuh yang dikeringkan dengan pengeringan kering angin dan oven serta nilai terendah yang diperoleh adalah air seduhan wedang uwuh yang dikeringkan dengan pengeringan matahari. Berdasarkan uji hedonik terhadap warna air seduhan wedang uwuh berkisar antara 5,00 - 5,13 (agak suka). Nilai tertinggi yang diperoleh adalah air seduhan wedang uwuh yang dikeringkan dengan pengeringan oven serta nilai terendah yang diperoleh adalah air seduhan wedang uwuh yang dikeringkan dengan pengeringan matahari.

\section{Aroma}

Aroma merupakan salah satu faktor yang digunakan sebagai penentu tingkat kesukaan panelis terhadap suatu produk. Aroma erat hubungannya dengan komponen volatil yang terdapat pada suatu bahan sehingga aroma yang terbentuk akan lebih tajam (Sutianik, 1999). Aroma merupakan parameter yang juga berpengaruh terhadap penerimaan konsumen. Berdasarkan hasil analisis sidik ragam dapat disampaikan bahwa aroma air seduhan wedang uwuh dengan berbagai metode berpengaruh tidak nyata $(\mathrm{P}>0,05)$. Hasil uji sensori terhadap warna seduhan wedang uwuh berkisar 
antara 4,73 - 5,00 (agak suka). Nilai tertinggi yang diperoleh adalah air seduhan wedang uwuh yang dikeringkan dengan pengeringan angin dan nilai terendah yang diperoleh adalah air seduhan wedang $u w u h$ yang dikeringkan dengan pengeringan oven.

\section{Rasa}

Rasa merupakan faktor yang sangat berpengaruh dan penentu tingkat kesukaan panelis terhadap suatu produk. Rasa berhubungan dengan komponen bahan yang dapat ditangkap oleh indera perasa seseorang. Analisis sidik ragam terhadap rasa seduhan wedang uwuh berkisar antara 4,13 - 4,46 (biasa). Nilai tertinggi yang diperoleh adalah air seduhan wedang uwuh yang dikeringkan dengan pengeringan matahari dan nilai terendah yang diperoleh adalah air seduhan wedang uwuh yang dikeringkan dengan pengeringan rumah kaca.

\section{Penerimaan keseluruhan}

Penerimaan air seduhan wedang uwuh secara keseluruhan, panelis agak suka terhadap aroma, warna dan rasa wedang uwuh $(\mathrm{P}>0,05)$. Seduhan wedang uwuh yang paling disukai panelis adalah air seduhan wedang uwuh dengan pengeringan matahari. Warna yang dihasilkan dari seduhan wedang uwuh memiliki pengaruh yang signifikan terhadap penerimaan produk wedang uwuh.

\section{KESIMPULAN DAN SARAN}

\section{Kesimpulan}

Berdasarkan penelitian yang telah dilakukan maka dapat disimpulkan beberapa hal sebagai berikut:

1. Wedang uwuh dengan metode pengeringan angin menghasilkan antioksidan dan total fenol tertinggi masing-masing sebesar 63,63 mgGAEAC/L dan 23,70 $\mathrm{mg} / \mathrm{L}$ dengan kadar air 8,05, dimana berdasarkan warna, aroma, rasa dan penerimaan keseluruhaan wedang uwuh panelis agak suka dengan seduhan wedang uwuh yang dihasilkan.

2. Metode pengeringan berpengaruh nyata terhadap kadar air simplisia wedang uwuh, total fenol dan kapasitas antioksidan air seduhan wedang uwuh, dan tidak berpengaruh nyata terhadap warna aroma rasa dan penerimaan keseluruhan.

\section{Saran}

Pengeringan simplisia sebaiknya menggunakan pengeringan kering angin agar mendapatkan hasil antioksidan yang tinggi.

\section{DAFTAR PUSTAKA}

Anonimous. 2013. Pembuatan wedang uwuh celup. Digilib UNS - Universitas Sebelas Maret. Diakses pada tanggal: 20 Januari 2018.

AOAC, 2005. Official Methods of Analysis. Assosiation of Official Chemist. Inc, Virginia.

Danthiswari, K., I.G.D.M. Permana dan N.M. Yusa. 2016. Kajian Pengaruh Jenis Jahe (zingiber officianale Rosc.) dan Waktu Pengeringan 
Daun Terhadap Kapasitas Antioksidan Serta Sensoris Wedang Uwuh. Jurnal Ilmu dan Teknologi Pangan (itepa) Vol.5, No.2. Universitas Udayana, Denpasar.

Departemen Kesehatan Republik Indonesia. (2008). Farmakope Herbal Indonesia (Edisi I). Jakarta: Departemen Kesehatan Republik Indonesia.

Gomez, KA. dan Gomez A.A., 1995. Prosedur Statistik untuk Penelitian Pertanian. Jakarta: UI-Press, hal : 13-16.

Hernani dan E. Hayani. 2001. Identification of chemical components on red ginger (Zingiber officinale var. Rubrum) by GCMS. Proc. International Seminar on natural products chemistry and utilization of natural resources. UI-Unesco, Jakarta: 501 - 505.

Katno. 2008. Tingkat Manfaat, Keamanan dan Efektifitas Tanaman Obat dan Obat Tradisional. Badan Penelitian dan Pengembangan Kesehatan Departemen Kesehatan RI. Karanganyar.

Kristianingrum, S. 2009. Pembuatan wedang uwuh celup. Jurdik Kimia FMIPA UNY. Diakses pada tanggal: 23 Januari 2018. Melalui: http://staff.uny.ac.id/sites/default/files/peng abdian/susila-kristianingrum-dra-msi/20.pdf

Manoi, F. 2006. Pengaruh Cara Pengeringan Terhadap Mutu Simplisia Sambiloto. Bull.Littro. 17 (1): 1-5.

Rivai, Harizzul, H. Nurdin, H. Suyani dan A. Bakhtiar. 2010. Pengaruh Cara Pengeringan Terhadap Perolehan Ekstraktif, Kadar Senyawa Fenolat Dan Aktivitas Antioksidan Dari Daun Dewa (Gynura Pseudochina (L.)Dc.). Majalah Obat
Tradisional, 15(1), 26 - 33. Universitas Andalas, Padang.

Rivai, Harrizul, Guswandi dan R. Wahyuni. 2014. Pengaruh Cara Pengeringan Dengan Oven, Kering Angin Dan Cahaya Matahari Langsung Terhadap Mutu Simplisia Herba Sambiloto. Jurnal Farmasi Higea, Vol. 6, No. 2. Universitas Andalas, Padang.

Sazalina. 2005. Optimisation of Operating Parameters for The Removal Of Ethanol From Zingiber Officinale Roscoe (Ginger) Oleoresin Using Short-Path Distillation. Master Thesis. Faculty of Chemical and Natural Resources. Engineering.Universiti Teknologi Malaysia, Hal 42-46

Soekarto, T. T. 1985. Penilaian organoleptik untuk industri pangan dan hasil pertanian, PUSBANGTEPA Food Technology Development Center Institut Pertanian Bogor.

Winangsih, E. Prihastanti dan S. Parman. 2013. Pengaruh Metode Pengeringan Terhadap Kualitas Simplisia Lempuyang Wangi (Zingiber aromaticum L.). Buletin Anatomi dan Fisiologi. 21(1), 19-25.

Winarno, F.G. (2002). Kimia pangan dan gizi. Jakarta: Gramedia pustaka Utama L. Sri, N. U. Purwanti dan K. N. Manihuruk. 2016. Pengaruh Cara Pengeringan Simplisia Daun Senggani (Melastoma malabathricum L.) Terhadap Aktivitas Antioksidan Menggunakan Metode DPPH (2,2-difenil-1pikrilhidrazil). Pharm Sci Res ISSN 24072354 (Vol. 3 No. 3).

Yun, L. 2001. Free Radical Scavenging Properties of Conjugated Linoic Acids. J. Agric. Food Chem. 49:3452

345 . 